\begin{tabular}{|c|c|c|}
\hline $\bar{A}$ & $\begin{array}{c}\text { International Journal of Current Research } \\
\text { and Academic Review }\end{array}$ & 售 \\
\hline $\begin{array}{l}\text { EXCELLENT } \\
\text { PUBLISHERS }\end{array}$ & $\begin{array}{c}\text { ISSN: 2347-3215 (Online) Volume } 9 \text { Number } 01 \text { (January-2021) } \\
\text { Journal homepage: http://www.ijcrar.com }\end{array}$ & \\
\hline
\end{tabular}

doi: https://doi.org/10.20546/ijcrar.2021.901.008

\title{
Effect of Organic and Inorganic Fertilizers on Agronomic Growth and Soil Properties of Coffee (Coffea arabica L.) at Jimma, Southwestern Ethiopia
}

\author{
Obsa Atnafu*, Mohammed Kedir, Ewnetu Teshale and Meseret Nugusie
}

Jimma Agricultural Research Center, Natural Resource Management, Ethiopia

*Corresponding author

\begin{abstract}
A field experiment was conducted at Jimma Agricultural Research Center, Agaro Agricultural Research Sub Center, southwestern Ethiopia for five consecutive cropping seasons from 2015/16 to 2019/20 to evaluate effect of organic (conventional compost) and inorganic NP fertilizers on agronomic growth and soil properties of coffee (Coffea arabica L.). The treatments consisted of $100 \%$ recommended decomposed coffee husk alone, $100 \%$ recommended NP rate alone, $100 \%$ of $\mathrm{NP}+25 \%$ of compost (DCH), $75 \%$ of $\mathrm{NP}+50 \%$ of compost $(\mathrm{DCH}), 50 \%$ of $\mathrm{NP}+50 \%$ of compost $(\mathrm{DCH}), 50 \%$ of $\mathrm{NP}+75 \%$ of compost $(\mathrm{DCH}), 25 \%$ of $\mathrm{NP}+75 \%$ of compost (DCH), $25 \%$ of NP $+100 \%$ of compost (DCH) and Control (without input, farmers' practice). The experiment was laid out in randomized complete block design with three replications. Higher yield of clean coffee yield was obtained from the application of $50 \%$ dose of nitrogen and phosphorous from inorganic fertilizer sources and 50\% dose of decomposed coffee husk $\left(2083.5 \mathrm{~kg} \mathrm{ha}^{-1}\right)$ while the lowest clean coffee yield $\left(1570.5 \mathrm{~kg} \mathrm{ha}^{-1}\right)$ was obtained from no application of fertilizers. Application of organic fertilizers (compost) with inorganic fertilizers gave statistically similar yield components to NP fertilizer alone for five years. Significant differences $(p>0.05)$ due to soil nutrient sources were observed in coffee height where inorganic fertilizer treatment resulted in tallest coffee plants $(348.23 \mathrm{~cm})$ and no application of nutrients having the shortest coffee trees $(200.49 \mathrm{~cm})$ after two year. Lower yield and yield components of Limu 1 coffee were achieved from no application of organic and inorganic fertilizer sources. In conclusion, organic fertilizers (conventional compost) alone cannot provide a viable substitute for inorganic fertilizer without causing a significant yield. Therefore, integrated use of organic and inorganic fertilizers was recommended for coffee production at Jimma, southwestern Ethiopia and other similar agro ecology.
\end{abstract}

\section{Introduction}

Coffee is the back bone of Ethiopia's economy and contributes largely to the national foreign currency income and accounts for more than $35 \%$ of the total major export commodities earnings (FAO/WFP, 2008). Furthermore, coffee plays a vital role both in the cultural

\section{Article Info}

Accepted: 08 December 2020

Available Online: 20 January 2021

\section{Keywords}

Coffee, Decomposed coffee husk, Integrated, Organic. 
Bayetta, 1991). However, the bulk of coffee is produced in the eastern, Southern and western parts of the country which have altitudes ranging from 1,300 to $1800 \mathrm{~m}$ above sea level.

There are two sources of nutrients (inorganic and organic) that can be applied in coffee field. Both organic and inorganic fertilizers provide plants with the nutrients needed to grow healthy and strong. However, each contains different ingredients and supplies these nutrients in different ways. Fertilizers supplement the soil with macronutrients needed in large amounts: nitrogen, phosphorus and potassium. However, organic and inorganic fertilizers do so via different materials. The use of inorganic fertilizers has been a significant contributor to increased crop productivity since the green revolution, and has resulted in reduced use of organic nutrient sources that farmers have relied for centuries (Satyanarayana et al., 2202). However, coffee in many parts of Africa is said to be "organic by default" not only due to the high cost and uncertain accessibility of inorganic fertilizers, but also due to a common assumption that coffee, as originally a forest crop (Wrigley, 1988), can survive "naturally through organic nutrients from litter fall (Maro et al., 2006). Organic inputs contain nutrients that are released at a rate determined in part by their biochemical characteristics or organic resource quality. However, organic inputs applied at realistic levels seldom release sufficient nutrients for optimum crop yield. Combining organic and mineral inputs has been advocated as a sound management principle for smallholder farming in the tropics because neither of the two inputs is usually available in sufficient quantities, because positive interactions between both inputs have often been observed (Vanlauwe et al, 2001) and because both inputs are needed in the long term to sustain soil fertility and crop production.

One of the major reasons behind the suboptimal use of inorganic fertilizers for grain crops is the costly price. Continuous production of crops against a backdrop of little fertilizer use over decades has aggravated the decline in soil fertility and crop yield (Gete et al., 2010; Sanchez et al., 1997; Getachew et al., 2014). The integration of organic fertilizers like vermicompost and conventional compost with inorganic sources may improve and sustain crop yields without degrading soil fertility status. Integration of organic and inorganic fertilizers improved the crop yield compared to fertilizers applied separately (Getachew et al., 2014). Integrated soil fertility management based crop production systems plays important roles in restoring soil fertility and availability of plant nutrients, enhancing crop growth and productivity (Gete et al., 2010; Vanlauwe et al., 2010). So, integrated nutrient management, in which both compost and inorganic fertilizers are used simultaneously, is the most effective method, particularly in developing countries where mineral fertilizers are high-priced. Therefore, the objective of this study was to evaluate the combined economically optimum rates of organic and inorganic fertilizers for Limmu-1 coffee under nitisols of Jimma, southwestern Ethiopia.

\section{Materials and Methods}

\section{Description of the study area}

The experiment was conducted at Jimma Agricultural Research Center at Agaro Agricultural Research Sub Center, Ethiopia for five consecutive cropping seasons from $2015 / 16$ to $2019 / 20$. The site is located at $45 \mathrm{~km}$ in the south west of the Jimma town at an altitude of 1630 m.a.s.l. It is situated at $7^{0} 50^{\prime} 35^{\prime \prime}-7^{0} 51^{\prime} 00^{\prime} ' \mathrm{~N}$ latitude and $36^{\circ} 35^{\prime} 30^{\prime \prime} \mathrm{E}$ longitude. The mean annual rainfall of the area is 1616 millimeters with average maximum and minimum temperatures of 28.4 and $12.4^{\circ} \mathrm{C}$, respectively. The major soil type is Mollic Nitisols with soil pH 6.20, organic mater $7.07 \%$, nitrogen $0.42 \%$, phosphorus 11.9

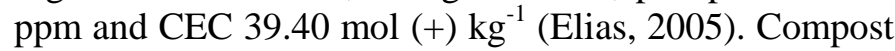
was prepared from locally available organic materials (coffee husk) according to the available procedure of compost preparation in the area. Selected Limmu-1 coffee variety was used for this trail.

\section{Procedure of piling (preparation of conventional compost)}

Maize straw at the bottom of the heap was about $5 \mathrm{~cm}$ thicknesses. This is important for keeping good ventilation; immediately on the maize straws, spread undecomposed coffee husk (left over of animal feed) to a thickness of about $20 \mathrm{~cm}$. The next layer was farm yard manure and/or chicken manure in $15 \mathrm{~cm}$ thickness; then add thin layer $(5 \mathrm{~cm}$ ) of kitchen (wood) ash; on top of this add thin layer $(5 \mathrm{~cm})$ of garden/forest soil to introduce beneficial microorganisms for decomposition; remember to sprinkle water after each layer (even twice in a layer) as required to make the layers moist but not wet or soggy; repeat the step above until your pile reaches the height of $130 \mathrm{~cm}$; cover the pit with broad leaves (like banana, enset, ...) and grasses. Every 21 days the materials was mixed and turned to next pit/bin. After two times turning, i.e. after 63 days the compost 
was ready for field application after air drying. Good decomposition can be detected by a pleasant odor, heat produced (this is even visible in the form of water vapor given off during the turning of the pile), growth of white fungi on the decomposing organic material, reduction of volume and by the change in color of the materials to brown. Hence, immediate correction have to be made in order to have good quality compost (dark brown to almost black in color, soft as breaking up readily and have earthy smell like forest floor).

Both organic materials were hand applied 21-30 days before sowing while compost was applied to plough depth. Compost rates were applied on the equivalency rates of inorganic fertilizers (To be adjusted in $\mathrm{N}$ content). The experiment was conducted on station which was fixed plots until the termination of the trial. The residual effects of compost were evaluated on these fixed fields. RCB design with three replications and plants were planted by $2 \mathrm{~m} * 2 \mathrm{~m}$ spacing. Integrated decomposed coffee husk (DCH) plus nitrogen and phosphorus fertilizer (NP).

\section{Experimental design}

The experiment was established in December, 2012, following a randomized complete block design with three replications. The following nine integrated organic and inorganic fertilizer treatments were evaluated. Namely;100\% recommended decomposed coffee husk (DCH) alone, $100 \%$ recommended NP rate alone, $100 \%$ of $\mathrm{NP}+25 \%$ of compost $(\mathrm{DCH}), 75 \%$ of $\mathrm{NP}+50 \%$ of compost $(\mathrm{DCH}), 50 \%$ of $\mathrm{NP}+50 \%$ of compost $(\mathrm{DCH})$, $50 \%$ of $\mathrm{NP}+75 \%$ of compost $(\mathrm{DCH}), 25 \%$ of $\mathrm{NP}+$ $75 \%$ of compost (DCH), $25 \%$ of $\mathrm{NP}+100 \%$ of compost $(\mathrm{DCH})$ and Control (without input, farmers' practice). The experiment was run for four years up to December, 2019. All the management practices such as shading, weeding and other agronomic practices were applied uniformly for all plots as recommendation.

\section{Data collection}

\section{Growth indicating parameters}

Growth characteristics were measured at the end of fourth and fifth year after planting. The plant height was measured from the base of the stem to the plant apex using graduated ruler. The diameter of the main stem was measured at full fruit bearing stage, $5 \mathrm{~cm}$ above the ground using Vernier Caliper (Assis et al., 2014; Tefera et al., 2016). The length of bearing primary branches was measured from the point of attachment to the main stem to the apex using graduated ruler as an average value of four longest bearing primaries per plant. Total number of bearing primary branches was estimated by counting the total number of bearing primaries per plant at full fruit bearing stage (Esther and Adomako, 2010).

\section{Yield and yield components}

Number of berry clusters or fruiting nodes was determined as an average number of clusters per plant from four heavily bearing primaries at the middle of the canopy towards all four directions (Etienne and Betrand, 2001). Yield was obtained by harvesting mature red cherries to get fresh weight per plot using gravimetric scale. Transformation of cherry weight to clean coffee weight was done using the conversion factor of 0.16 for Arabica coffee as recommended by (ICO, 2011).

\section{Data processing and analysis}

Data were subjected to ANOVA using Statistics SAS software and means were separated using Fisher LSD method at 0.05 significance level.

\section{Results and Discussions}

Effect of integrated organic and inorganic nutrient source on soil chemical properties

Results of soil analysis after harvesting of coffee revealed that the application of different organic and inorganic fertilizer rates affected soil $\mathrm{pH}$, organic carbon and total $\mathrm{N}$. The results of soil analysis revealed that the soil $\mathrm{pH}$ value ranged 4.87-5.54; organic carbon content of the soil is $2.22-3.09 \%$ and total nitrogen content of the soil amounts to $0.21-0.31 \%$ (Table 1). Berhanu (1980) classified soils with organic matter $>5.20,2.6-5.2,0.8$ 2.6 and $<0.8 \%$ as high, medium, low and very low, respectively in their organic matter status. Therefore, the organic carbon content 2.22-3.09\% of the experimental soil is medium. According to Landon (1991) soils having total $\mathrm{N}$ of greater than $1.0 \%$ are classified as very high, $0.5-1.0 \%$ high, $0.2-0.5 \%$ medium, $0.1-0.2 \%$ low and less than $0.1 \%$ as very low in total nitrogen content. Therefore, the soil of the experimental site has medium total nitrogen content $0.21-0.31 \%$. Bruce and Rayment (1982) classified soils having $\mathrm{pH}$ with $<4.5,4.5-5,5.1-$ 5.5, 5.6-6 and 6.1-6.5 as extremely acid, very strongly acid, strongly acid, moderately acid and slightly acid, respectively in $\mathrm{pH}$ value content. The $\mathrm{pH}$ of the soil was analyzed to be 4.87-5.54 showing very strongly acid and 
strongly acid reach. Soil $\mathrm{pH}$ of coffee fields was affected by different soil fertility management treatments.

\section{Soil pH}

Soil $\mathrm{pH}$ was significantly $(P<0.05)$ affected by application of NP and coffee husk compost (Table 1). The highest soil $\mathrm{pH}$ (5.54) was recorded from application of $25 \% \mathrm{NP}$ and $75 \%$ decomposed coffee husk followed by the control (5.53) while, the lowest soil $\mathrm{pH}$ (4.87) was obtained from application of NP fertilizer alone (Table 1). The result revealed improvement in soil $\mathrm{pH}$ was by $13.76 \%$ over the $100 \% \mathrm{NP}$ (4.87 to 5.54 ) (Table 1 ). The increment of soil $\mathrm{pH}$ might be ascribed to the alkalinity of applied compost as noted from its high $\mathrm{pH}$ value (Table 1). Similarly, increase in soil $\mathrm{pH}$ due to the application of composts with high $\mathrm{pH}$ value was also reported by Kasongo et al. (2011).

\section{Soil organic carbon}

Soil organic carbon was highly significantly $(P<0.05)$ affected by application of inorganic (NP) fertilizer and coffee husk compost (Table 1). The application of amendments with various levels increased soil organic carbon over the control treatment (Table 1). The highest soil organic carbon (3.09\%) was recorded from application of $75 \% \mathrm{NP}$ and $50 \%$ decomposed coffee husk whereas; the lowest soil organic carbon (2.22\%) was recorded from $50 \% \mathrm{NP}$ and $75 \% \mathrm{DCH}$ plots. The increase in soil organic carbon following application of compost might be attributed to the high content of organic matter in the coffee husk compost (Table 1). In line with this finding Tesfaye et al. (2019) also reported that increase in soil organic matter following application of filter cake compost and vinasse to soils.

\section{Soil total nitrogen}

Total soil nitrogen was significantly $(\mathrm{P}<0.05)$ affected by application of organic and inorganic fertilizers (Table $1)$. The highest soil total nitrogen $(0.31 \%)$ was recorded from application of $100 \% \mathrm{NP}$ followed by application of $50 \% \mathrm{NP}+50 \% \mathrm{DCH}$ and $100 \% \mathrm{DCH}$. The lowest soil total nitrogen $(0.21 \%)$ was obtained from the control plot. The highest soil total nitrogen recorded from $100 \%$ coffee husk compost over the control might be due to releasing of Nitrogen from organic matter as a result of mineralization.

\section{Effect of integrated organic and inorganic fertilizer on coffee growth parameters}

The analyses of variance for yield components of Limmu-1 coffee are indicated in (Fig. 1 and 2). Inorganic fertilizer produced the tallest coffee $(\mathrm{p}<0.05)$ with a final height of $348.23 \mathrm{~cm}$. Combining inorganic and organic fertilizers performed better than just organic fertilizers alone in both the mean height and the final height of the coffee. Application of organic and inorganic fertilizers significantly affected most of the Limmu-1 coffee parameters measured except for plant height, number of primary branches at first year (Fig. 1 and 2). Significant variations were observed on yield and yield components of Limmu coffee due to year effect indicating temporal variations across cropping seasons.

Table.1 Effect of organic and inorganic fertilizer application on soil nutrient status for coffee

\begin{tabular}{llll}
\hline Treatments & \multicolumn{3}{c}{ Parameters tested } \\
\cline { 2 - 4 } & $\mathrm{pH}\left(\mathrm{H}_{2} \mathrm{O}\right)$ & $\mathrm{TN}(\%)$ & $\mathrm{OC}(\%)$ \\
\hline $100 \% \mathrm{DCH}$ & $5.18^{\mathrm{ab}}$ & $0.27^{\mathrm{ab}}$ & $2.32^{\mathrm{e}}$ \\
$100 \% \mathrm{NP}$ & $4.87^{\mathrm{b}}$ & $0.31^{\mathrm{a}}$ & $2.87^{\mathrm{b}}$ \\
$100 \% \mathrm{NP}+25 \% \mathrm{DCH}$ & $5.49^{\mathrm{a}}$ & $0.23^{\mathrm{bc}}$ & $2.49^{\mathrm{d}}$ \\
$75 \% \mathrm{NP}+50 \% \mathrm{DCH}$ & $5.07^{\mathrm{ab}}$ & $0.26^{\mathrm{abc}}$ & $3.09^{\mathrm{a}}$ \\
$50 \% \mathrm{NP}+50 \% \mathrm{DCH}$ & $5.31^{\mathrm{ab}}$ & $0.28^{\mathrm{ab}}$ & $2.57^{\mathrm{d}}$ \\
$50 \% \mathrm{NP}+75 \% \mathrm{DCH}$ & $5.27^{\mathrm{ab}}$ & $0.21^{\mathrm{c}}$ & $2.22^{\mathrm{e}}$ \\
$25 \% \mathrm{NP}+75 \% \mathrm{DCH}$ & $5.54^{\mathrm{a}}$ & $0.24^{\mathrm{bc}}$ & $2.69^{\mathrm{c}}$ \\
$25 \% \mathrm{NP}+100 \% \mathrm{DCH}$ & $5.42^{\mathrm{ab}}$ & $0.24^{\mathrm{bc}}$ & $2.52^{\mathrm{d}}$ \\
$\mathrm{Control}$ & $5.53^{\mathrm{a}}$ & $0.21^{\mathrm{c}}$ & $2.73^{\mathrm{c}}$ \\
\hline Mean & 5.3 & 0.25 & 2.61 \\
LSD $(0.05)$ & 0.62 & $0.05^{*}$ & $0.11^{* * *}$ \\
$\mathrm{CV}(\%)$ & 6.73 & 11.94 & 2.51 \\
\hline
\end{tabular}


Table. 2 Effect of integrated organic and inorganic fertilizers application on clean coffee yield

\begin{tabular}{lllllll}
\hline Treatments & \multicolumn{5}{c}{ Clean Coffee yield kg/ha } \\
\cline { 2 - 6 } & $2015 / 16$ & $2016 / 17$ & $2017 / 18$ & $2018 / 19$ & $2019 / 20$ & Over year \\
\hline $100 \% \mathrm{DCH}$ & $1008.7^{\mathrm{b}}$ & $1663.5^{\mathrm{cd}}$ & $1665.4^{\mathrm{e}}$ & $2433.3^{\mathrm{ab}}$ & $2536.7^{\mathrm{ab}}$ & $1861.52^{\mathrm{b}}$ \\
$100 \% \mathrm{NP}$ & $1143.2^{\mathrm{ab}}$ & $1725.7^{\mathrm{bcd}}$ & $2049.7^{\mathrm{abcd}}$ & $2176.7^{\mathrm{bc}}$ & $2216.7^{\mathrm{b}}$ & $1862.4^{\mathrm{b}}$ \\
$100 \% \mathrm{NP}+25 \% \mathrm{DCH}$ & $1228.1^{\mathrm{a}}$ & $2104.5^{\mathrm{a}}$ & $1788^{\mathrm{de}}$ & $2293.3^{\mathrm{bc}}$ & $2303.3^{\mathrm{b}}$ & $1943.5^{\mathrm{b}}$ \\
$75 \% \mathrm{NP}+50 \% \mathrm{DCH}$ & $1118.4^{\mathrm{ab}}$ & $1861^{\mathrm{abc}}$ & $1911.1^{\mathrm{bcde}}$ & $2376.7^{\mathrm{b}}$ & $2380^{\mathrm{b}}$ & $1929.4^{\mathrm{b}}$ \\
$50 \% \mathrm{NP}+50 \% \mathrm{DCH}$ & $1021.1^{\mathrm{b}}$ & $1563.3^{\mathrm{d}}$ & $2299.8^{\mathrm{a}}$ & $2733.3^{\mathrm{a}}$ & $2800^{\mathrm{a}}$ & $2083.5^{\mathrm{a}}$ \\
$50 \% \mathrm{NP}+75 \% \mathrm{DCH}$ & $800.7^{\mathrm{c}}$ & $1232.1^{\mathrm{e}}$ & $1872.5^{\mathrm{cde}}$ & $2066.7^{\mathrm{cd}}$ & $2150^{\mathrm{bc}}$ & $1624.4^{\mathrm{cd}}$ \\
$25 \% \mathrm{NP}+75 \% \mathrm{DCH}$ & $1235.7^{\mathrm{a}}$ & $1956.4^{\mathrm{ab}}$ & $1935.4^{\mathrm{bcde}}$ & $2233.3^{\mathrm{bc}}$ & $2133.3^{\mathrm{bc}}$ & $1898.8^{\mathrm{b}}$ \\
$25 \% \mathrm{NP}+100 \% \mathrm{DCH}$ & $1125.6^{\mathrm{ab}}$ & $1774.4^{\mathrm{bcd}}$ & $2136.9^{\mathrm{abc}}$ & $1766.7^{\mathrm{de}}$ & $1753.3^{\mathrm{cd}}$ & $1711.4^{\mathrm{c}}$ \\
$\mathrm{Control}$ & $757.4^{\mathrm{c}}$ & $1693.5^{\mathrm{bcd}}$ & $2161.8^{\mathrm{ab}}$ & $1583.3^{\mathrm{e}}$ & $1656.7^{\mathrm{d}}$ & $1570.5^{\mathrm{d}}$ \\
\hline Mean & 1048.8 & 1730.5 & 1980.1 & 2184.8 & $2214.4^{*}$ & 1831.7 \\
LSD $(0.05)$ & $199.9^{* *}$ & $266.7^{* *}$ & 275.1 & $307.4^{* *}$ & $410.1^{* *}$ & $126.9^{* *}$ \\
CV $(\%)$ & 11.01 & 8.91 & 8.03 & 8.13 & 10.70 & 9.55 \\
\hline
\end{tabular}

Figure.1 Effect of organic and inorganic fertilizer on growth parameters of coffee

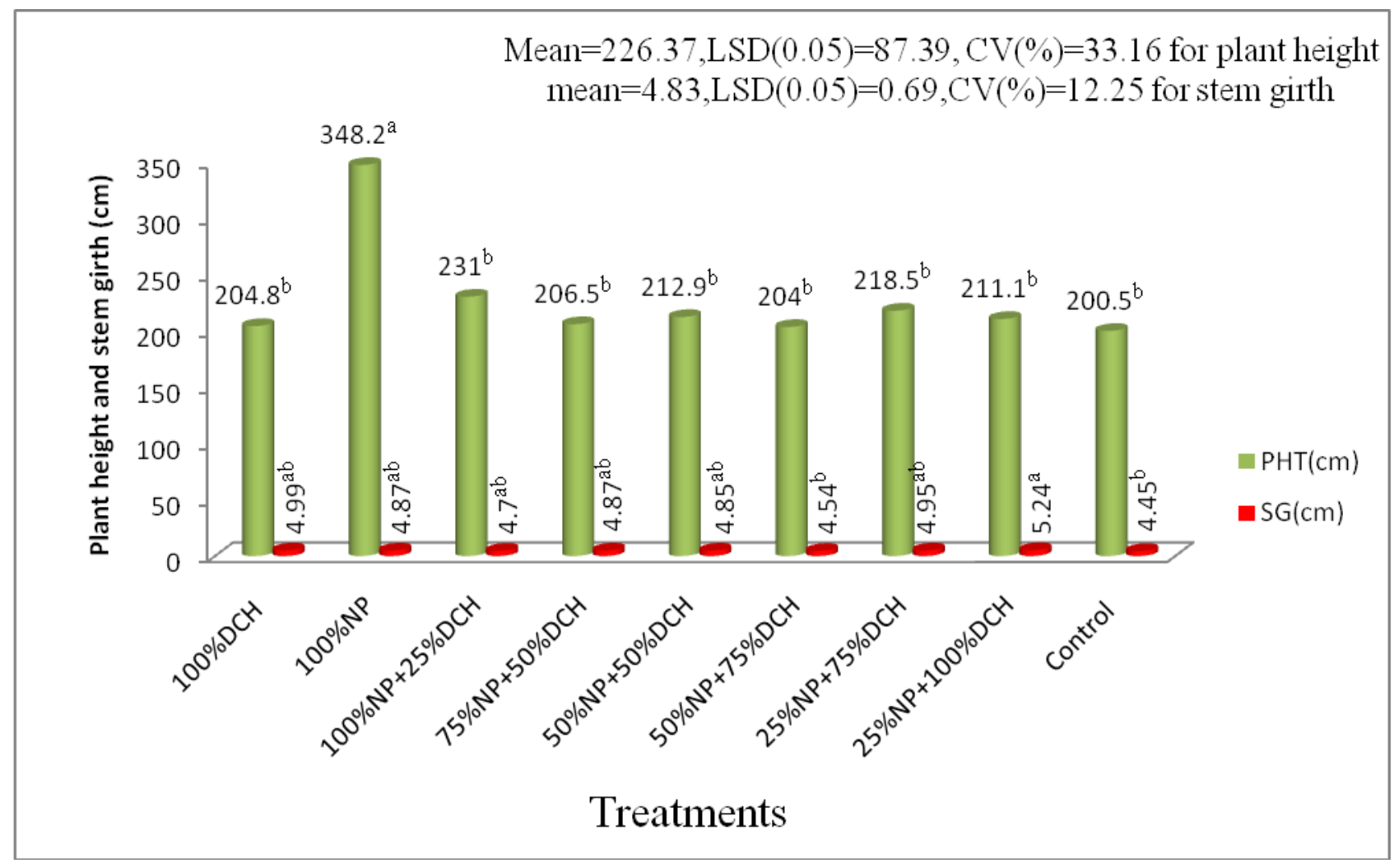


Figure.2 Effect of organic and inorganic fertilizer on number of primary branches

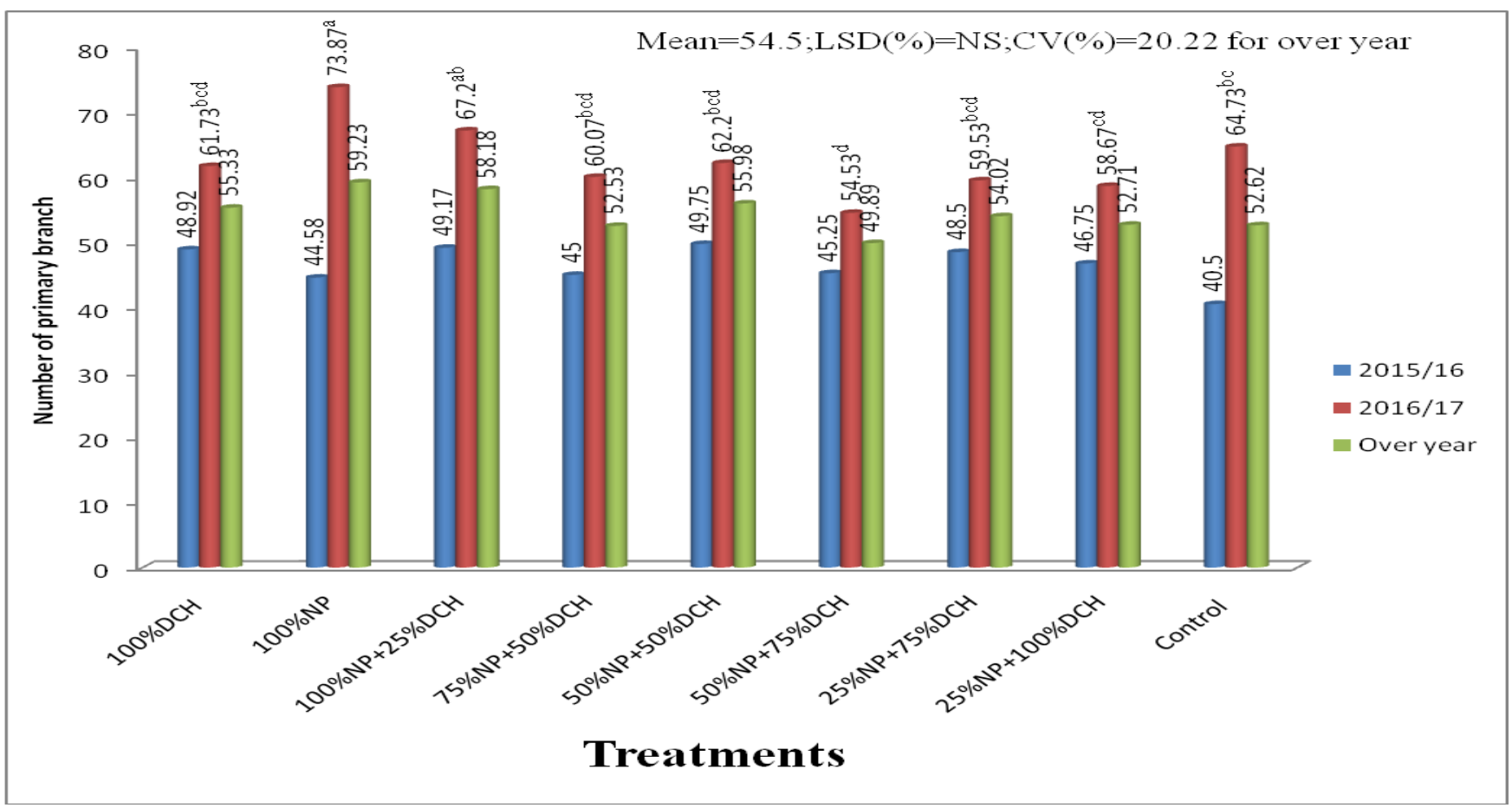

Figure.3 Effect of organic and inorganic fertilizers on canopy diameter of coffee at Agaro

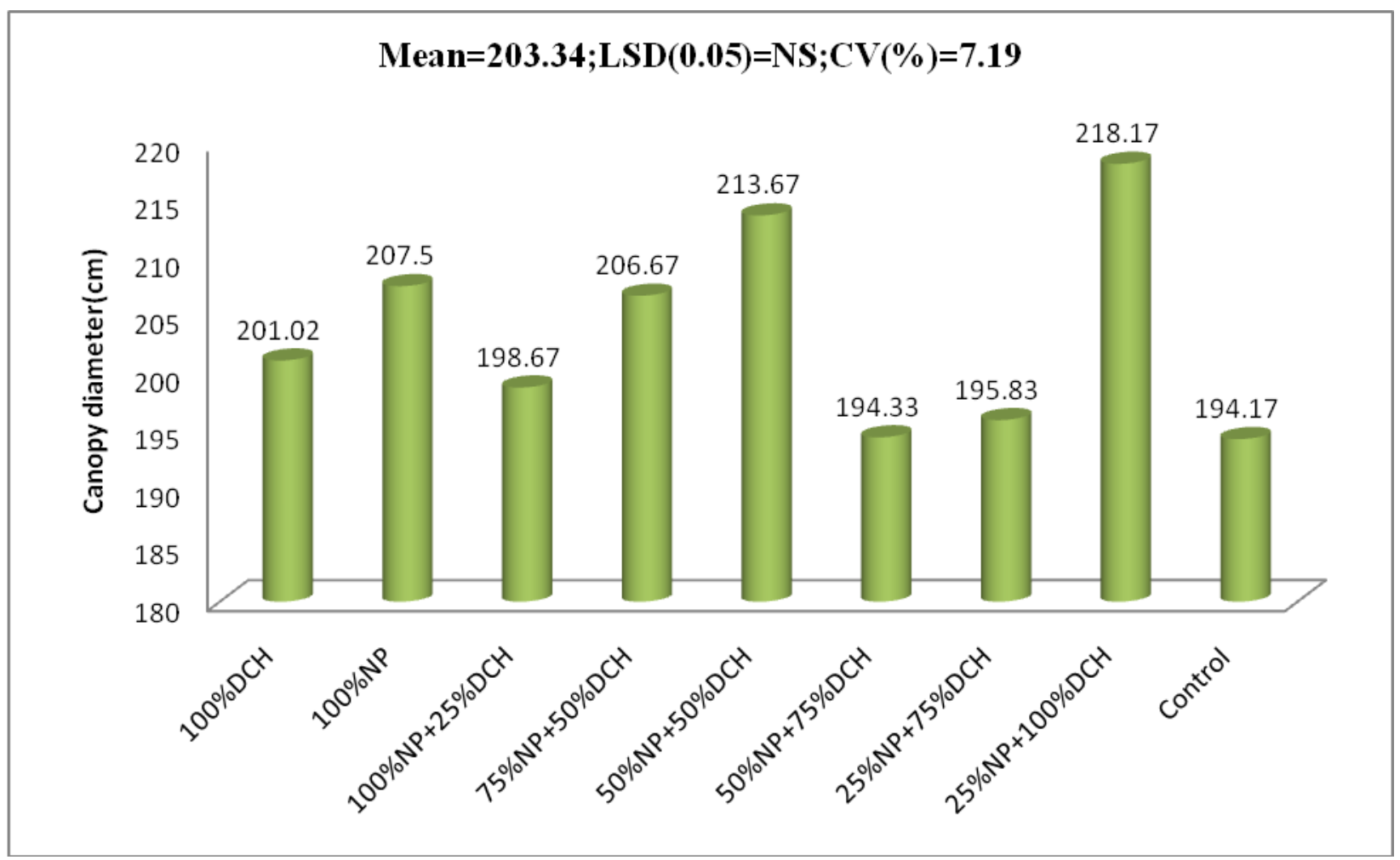




\section{Plant height}

The mean plant height of coffee was significantly ( $p$ $<0.05$ ) affected with application of organic and inorganic fertilizer rate. The maximum plant height $(348.23 \mathrm{~cm})$ of coffee was recorded from application of $100 \%$ NP while the lowest plant height $(200.97 \mathrm{~cm})$ of coffee height was obtained from the control plot (Fig.1). Coffee plant height recorded from combined fertilizer application was non-significant to each other. The increased plant height of coffee over the control in response to the mixed application of the fertilizers might be attributed to the released major nutrients and improved soil physical property in enhancing plant growth owing to their contribution to enhanced cell division, stem elongation, promotes leaf expansion and vegetative growth of plants (Muluneh, 2018). Similarly, Chemura (2014) reported that combining inorganic and organic fertilizers performed better than just organic fertilizers alone in both the mean height and the final height of the coffee seedlings.

\section{Number of primary branches}

The overall number of Primary branches/plant of coffee was non-significant. However, application of $100 \%$ NP and fertilizer produced the highest number of branches (59.23) followed by 58.18 from $100 \% \mathrm{NP}+25 \%$ decomposed coffee husk compost (Fig.2). While the least number of branches plant ${ }^{-1}$ of coffee was recorded from $50 \% \mathrm{NP}+75 \% \mathrm{DCH}$ plots (49.89) (Fig. 2). This might be due to positive effect of compost fertilizer on soil physical properties and on availability of major nutrients for coffee plant growth. Similarly, Chemura (2014) reported increase of number of branches per plant of coffee due to application of compost soils.

\section{Stem girth of coffee}

The stem girth of coffee was showed significant ( $\mathrm{p}<$ 0.05) difference due to treatments (Fig. 1). The maximum mean stem girth $(5.24 \mathrm{~cm})$ of coffee was recorded from application of 25\% NP $+100 \%$ decomposed coffee husk (DCH) while, the lowest mean stem girth $(4.45 \mathrm{~cm})$ of coffee plant was recorded from control without application of any fertilizer. The maximum mean girth recorded from $25 \%$ NP $+100 \%$ decomposed coffee husk (DCH)over the control might be due to more nutrients gained from both compost and NP integrated fertilizers. The result was in line with, Bikila (2018) who reported that there was positive effect of application of combined amendments on stem diameter of coffee seedlings.
Integrated application of organic and inorganic fertilizers showed highly significant $(\mathrm{P}<0.001)$ difference on plant height and number of primary branches of coffee at second year (Fig. 1 and 2). The highest number of primary branches (59.23), stem girth (5.31) and plant height $(348.23 \mathrm{~cm})$ were obtained from the application of the recommended rate of $\mathrm{N}$ and $\mathrm{P}$ from inorganic fertilizer (Fig. 1 and 2). Application of full dose of $\mathrm{N}$ and $\mathrm{P}$ from conventional compost or in combination to each other resulted in inferior plant heights, stem girth and number of primary branches. The lowest number of primary branches, stem girth and plant height were obtained from the application of no nutrients applied at all.

\section{Canopy diameter}

There were no significant differences among application of integrated organic and inorganic fertilizers in the growth of canopy diameter of coffee plants. Accordingly the highest result obtained from the application of $100 \%$ NPS fertilizer with non-significant difference in treatment (Fig. 3). Even if the result were nonsignificance between the treatments it was highly significant over the control. The results were in agreement with Chemura (2014) which reported that there were no significant differences between the slopes of girth and number of primaries $(p \leq 0.05)$ between organic, integrated and inorganic fertilizer options over time.

The application of organic and inorganic fertilizers significantly $(\mathrm{P}<0.05)$ increased the mean clean coffee yield (Table 2). The highest clean coffee yield (2083.5 $\mathrm{kg} \mathrm{ha}^{-1}$ ) was recorded from the application of half dose of the recommended rate of nitrogen and phosphorous from conventional compost and the remaining half dose from inorganic fertilizer (DAP and urea) (Table 2). This treatment gave grain yield advantage of $221.1 \mathrm{~kg} \mathrm{ha}^{-1}$ compared to application of the whole dose of recommended rate of $\mathrm{N}$ and $\mathrm{P}$ from inorganic fertilizer and $221.98 \mathrm{~kg} \mathrm{ha}^{-1}$ from conventional compost $(\mathrm{DCH})$ alone. Application of the recommended dose of $\mathrm{N}$ and $\mathrm{P}$ from inorganic fertilizers produced $1862.4 \mathrm{~kg} \mathrm{ha}^{-1}$ of clean coffee yield (Table 2). Application of half dose of the recommended rate of $\mathrm{N}$ and $\mathrm{P}$ from conventional compost and the remaining half dose from inorganic fertilizer gave the highest clean coffee yield all years except at first and second year (Table 2). Application of half of the recommended rate of $\mathrm{N}$ and $\mathrm{P}$ from conventional compost and inorganic fertilizers gave clean coffee yield advantage as compared to application 
of $\mathrm{N}$ and $\mathrm{P}$ from either recommended inorganic or compost alone (Table 2). Therefore, application of $\mathrm{N}$ and $\mathrm{P}$ from conventional compost alone did not bring significant increase of mean clean coffee yield (Table 2) indicating the slow release of nutrients from organic fertilizer sources.

In order to maintain soil fertility, reduce cost of inorganic fertilizers and sustain clean coffee yield production, farmers of the study area and similar agro ecologies are advised to make integrated use of organic conventional compost and inorganic fertilizers. Application of half dose of the recommended rate of $\mathrm{N}$ and $\mathrm{P}$ from conventional compost and the remaining half from inorganic fertilizers has been advised as the top priority management option even though other alternatives are still available.

Summary and conclusion are as follow:

The results indicated that organic and inorganic nutrient sources are able to provide sufficient nutrients for healthy coffee growth. The use of integrated organic and inorganic fertilizers could be the most attractive option given that it reduces on both costs of inorganic fertilizers and also on quantities of composts required for efficient coffee growth. Integrated application of organic and inorganic fertilizers significantly increased the yield and yield components of Limmu- 1 coffee. The highest clean coffee yield $\left(2083.5 \mathrm{~kg} \mathrm{ha}^{-1}\right)$ was recorded from the application of half dose of the recommended rate of nitrogen and phosphorous from conventional compost and the remaining half dose from inorganic fertilizer $(50 \% \mathrm{DCH}+50 \% \mathrm{NP})$. Application of the whole dose of $\mathrm{N}$ and $\mathrm{P}$ from conventional compost alone or inorganic fertilizers did not bring significant yield increase of Limmu-1 coffee variety. The use of integrated soil fertility management is the most appropriate option in the study area given that it reduces costs of inorganic fertilizers to about $50 \%$ without compromising efficient coffee growth and yield.

\section{References}

Agegnehu, G., B.Lakew and P.N.Nelson, 2014. Cropping sequence and nitrogen fertilizer effects on the productivity and quality of malting barley and soil fertility in the Ethiopian highlands. Archives of Agronomy and Soil Science, 60(9), pp.1261-1275.

Assis, G. A., M.S. Scalco, R. J. Guimaraes, A. Colombo, A.W. Dominghetti and N. Matos, 2014. Drip irrigation in coffee crop under different planting densities: Growth and yield in southeastern Brazil. Rev. Bras. De Engenharia Agric. Ambient. 8(11):116-11123.

Bayetta B., 1991. Hetrosis and combing ability study in arabica coffee. MSc. Thesis, Alemaya University of Agriculture, Ethiopia.

Berhanu Debele, 1980. The physical criteria and their rating proposed for land evaluation in the highland region of Ethiopia. Land use planning and regulatory department, Ministry of Agriculture. Addis Ababa, Ethiopia.

Bikila Takala, 2018. Effects of Lime and Compost on acidic Soil Amelioration and Growth of Coffee (Coffea Arabica L.) Seedlings at Haru, West Wollega. M.Sc. Thesis Submitted to School of Graduate Studies of Jimma University College of Agriculture and Veterinary Medicine, Department of Natural Resource Management.

Bruce, R.C., and G.E. Rayment, 1982. Analytical methods and interpretations used by the agricultural Chemistry Branch for soil and land use surveys. Queensland Department of Primary Industries. Bulletin QB8 (2004), Indooroopilly, Queensland.

Chemura, Abel,2014. The growth response of coffee (Coffea Arabica L.) plants to organic manure, inorganic fertilizers and integrated soil fertility management under different irrigation water supply levels. International Journal Recycling Organic Waste Agriculture, 3, 1-9.

Elias, A. 2005. Economics of coffee bean marketing: A case study of Gomma woreda in Jimma Zone of Ethiopia. M.Sc. Thesis, Graduate Studies of Haramaya University, Haramaya, Ethiopia.

Esther, A.K and B. Adomako, 2010. Genetic and environmental correlations between bean yield and agronomic traits in Coffea canephora. J. Plant Breed. Crop Sci. 2(4): 64-72.

Etienne, H and B. Betrand, 2001. True-to-type and agronomic characteristics of Coffea Arabica trees micro propagated by the embryogenic cell suspension technique. Tree Physiol. 21:1031-1038.

FAO, F., 2013. World Food and Agriculture Statistical Year book. FAO-Food \& Agriculture Organization of the United Nation, Rome, Italy.

FAO.and WFP., 2008. Special report FAO/WFP crop and food supply assessment mission to Ethiopia. January 24, 2008. http://www.fao.org/3/ah880e/ ah880e00.htm.

International Coffee Organization (ICO), 2011. World coffee trade conversions and statistics. [http://www .intracen.org/coffee guide/ world-coffee- 
trade/conversions-and-statistics] site visited on 20/7/2016.

Kasongo,R.K., A.Verdoodt, P. Kanyankagote, G. Baert and E.Van Ranst, 2011. Coffee Waste as an Alternative Fertilizer with Soil Improving Properties for Sandy Soils in Humid Tropical Environments. Soil Use and Management, 2, 94-102.

Landon, J.R. 1991. Booker Tropical Soil Manual: a handbook for soil survey and agricultural land evaluation in the tropics and subtropics. (Ed.). New York, John Wiley and Sons Inc.

Maro, G. P., H. E., Monyo E. O. Nkya, and J. M. Teri, 2006. The soil fertility status of coffee growing areas in Tanzania. In: Proceedings of ASIC, 21 September 2006, Montpellier Cedex, France. pp. 1419-1422.

Muluneh Siraj, 2018. Effect of Blended NPSB fertilizer rates on Growth yield and yield related traits of Potato (Solanum tuberosum L.) Varieties under Irrigation in Degem.M.sc. thesis Submitted to School of Plant Sciences Haramaya University.

Paulos, D. and D. Teketay, 2000. The need for forest coffee germplasm conservation in Ethiopia and its significance in the control of coffee diseases. Proceedings of the Workshop on Control of Coffee Berry Disease (CBD) in Ethiopia, Aug. 13-15, Addis Ababa, Ethiopia, pp: 125-135.

Sanchez, P.A., K.D. Shepherd, M.J. Soule, F.M. Place, R.J. Buresh, A.M.N. Izac, A. UzoMokwunye, F.R. Kwesiga, C.G. Ndiritu and P.L. Woomer, 1997. Soil fertility replenishment in Africa: an investment in natural resource capital. Replenishing soil fertility in Africa, 51, pp.1-46.

Satyanarayana, V., P. Prasad, V. Murthy, and K. Boote, 2002. Influence of integrated use of farmyard manure, inorganic fertilizers on yield and yield components of irrigated lowland rice, J. Plant. Nutr., 25(10).

How to cite this article:

Obsa Atnafu, Mohammed Kedir, Ewnetu Teshale and Meseret Nugusie. 2021. Effect of Organic and Inorganic Fertilizers on Agronomic Growth and Soil Properties of Coffee (Coffea arabica L.) at Jimma, Southwestern Ethiopia. Int.J.Curr.Res.Aca.Rev. 9(01), 86-94. doi: https://doi.org/10.20546/ijcrar.2021.901.008
Sertsu, S., A. Esayas and D. Tafesse, 2003. Soils of Kulumsa agricultural research center. Federal Democratic Republic of Ethopia.

Tefera, F., S Alamerew and D. Wagery, 2016. Assessment of the growth and yield characters of some promising Arabica coffee hybrids under highland environments in Southwestern Ethiopia. J. American- Eurasian J. Agric. Environ. Sci. 16(5): 917-923.

Tesfaye Wakgari, Kibebew Kibret, Bobe Bedadi, Melesse Temesgen and Teklu Erikossa, 2019. Effects of Sub-soiling and Organic Amendments on Selected Soil Physicochemical Properties and Sugar Yield in Metahara Sugar Estate. American- Eurasian Journal of Agricultural Research, 19,312-325.

Vanlauwe, B., A. Bationo, J. Chianu, K.E. Giller, R. Merckx, U. Mokwunye, O. Ohiokpehai, P. Pypers, R. Tabo, K.D. Shepherd and E.M.A. Smaling, 2010. Integrated soil fertility management: operational definition and consequences for implementation and dissemination. Outlook on agriculture, 39(1), pp.1724.

Vanlauwe, B., J. Wendt and J. Diels, 2001. Combined application of organic matter and fertilizer. Sustaining soil fertility in West Africa, 58, pp.247-279.

Workafes, W.T. and K. Kassu, 2000. Coffee production system in Ethiopia. Proceedings of the Workshop on Control of Coffee Berry Disease in Ethiopia, Aug. 13-15, EARO, Addis Ababa, Ethiopia, pp: 99-106.

Wrigley, G., 1988. Coffee: Tropical Agriculture Series. Longman Scientific and Technical, John Wiley and Sons Inc., New York, USA.pp.1-60.

Zelleke, G., G. Agegnehu, D. Abera, and S. Rashid, 2010. Fertilizer and soil fertility potential in Ethiopia. International food policy institute: Working Paper. 